\title{
NAZORY, POLENDIRA
}

Brigádní generál Ing. Jaromír Zůna, Ph.D., MSc., podplukovník Ing. Bohuslav Pernica, Ph.D.

Některá fakta k tématu vojensko-odborná kvalifikace důstojníků

\section{Some Remarks about the Professional Military Education of Officers}

\section{Abstrakt:}

Každý di̊stojník je povinen splnit kvalifikační požadavky stanovené pro konkrétní služební zařazení. Vnitřní, vojensky specifické požadavky lze splnit absolvováním př́slušného kurzu zabezpečovaného nebo organizovaného pod záštitou Ministerstva obrany. Vozbrojených silách ČR se již 20 let vede diskuze o podobě systému modelů kurzů, do kterých jsou vojáci vysíláni v průběhu trváni služebního poměru. I když se systém vzděláváni důstojniků stále mèni, jistým ekonomickým paradoxem přitom je, že počet osob, které zastávaji dané misto, aniž by splňovaly potrebou kvalifikaci, dlouhodobě neklesá, avšak zároveň tu existuje skupina vojáků, kteři sice překračuji kvalifikačni požadavky pro své stávající služební zařazení, ale ve své kariéře nepostupují. Nicméně právě na základě stanovených kvalifikačních požadavků je na nich vyžadováno absolvováni dalšich a dalšich vzdělávacích aktivit.

\section{Abstract:}

Each officer is obligated to meet his or her qualification requirements, identified in the job description. In order to obtain a required military qualification, officers are usually send to a training course, which is either provided or organized under the auspice of the Ministry of Defence. The discussion within the Armed Forces of the Czech Republic about the system of military courses has been ongoing for the last two decades. Although the system of officers' development is periodically reviewed, a certain economic paradox still remains. While the number of officers without adequate qualification is not diminishing, at the same time there is a segment of officers who exceed their qualification requirements, but they do not make any progress in their military careers. Despite the situation, these officers are required to take additional training and educational activities.

\section{Klíčová slova:}

Kvalifikace, kvalifikační požadavek, kurz, odborný výcvik, zákon o vysokých školách, univerzita, důstojník, Ministerstvo obrany, Bílá kniha o obraně, výstavba ozbrojených sil.

\section{Key Words:}

Qualification, job requirement, training course, professional training, the Higher Education Act, university, officer, Ministry of Defence, White Paper on Defence, development of armed forces. 


\section{Úvod}

První vysokoškolský zákon, zákon č. 58/1950 Sb., o vysokých školách, v § 2 hovořil o tom, že tehdejším:

„Úkolem vysokých škol, jako škol nejvyššiho stupně, je vychovávat odborně i politicky vysoce kvalifikované pracovníky, věrné lidově demokratické republice a oddané myšlence socialismu, tvořivě védecky a umělecky pracovat a spolupracovat na šírení vědy a umění mezi lidem. “"

Od roku 1950 došlo k přijetí dalších vysokoškolských zákonů, ve kterých byl nejenom postupně zpřesňován účel vysokých škol reflektujících společenskopolitický vývoj, ale také podrobněji specifikovány úkoly vysokých škol. Současný vysokoškolský zákon, zákon č. 111/1998 Sb., ve znění pozdějších předpisů, definuje v § 1 vysoké školy již jako nejvyšší článek vzdělávací soustavy, vrcholná centra vzdělanosti, nezávislého poznání a tvůrčí činnosti, mající klíčovou úlohu ve vědeckém, kulturním, sociálním a ekonomickém rozvoji společnosti, a specifikuje šest bodů, prostřednictvím kterých se naplňuje sociálně-ekonomický účel vysokých škol.

Jedním z nich je povinnost hrát: ,, ...aktivní roli ve veřejné diskuzi o společenských a etických otázkách, při pěstování kulturní rozmanitosti a vzájemného porozuméní, při utvárení občanské společnosti a př́pravě mladých lidí pro život v ní. "I takto lze chápat stanovisko dvou představitelů Univerzity obrany v jejich př́íspěvku ve Vojenských rozhledech č. 3/2013. [1] Proto se chceme touto cestou připojit k jejich vstupu do této veřejné diskuze pohledem na efektivitu př́ípravy vyšších důstojníků, a také zpřesnit a zařadit do aktuálního kontextu prezentované informace.

\section{Poloplná, nebo poloprázdná láhev?}

Ke změně celkového způsobu přípravy vyšších důstojníků obvykle dochází za situace, kdy se podstatně mění podmínky pro činnost ozbrojených sil. Př́ikladem může být transformační proces, v jehož průběhu se mění účel, typ a velikost ozbrojených sil daného státu. Jiným důvodem pro změnu, v praxi běžnějším, může být vyčerpání potenciálu existujícího uspořádání, které již nedostačuje novým požadavkům, a obvykle vede $\mathrm{k}$ potřebě změnit paradigma přípravy vyšších důstojníků. Jde o jev, ke kterému v armádách periodicky dochází a je pouze prrirozené, že se tak děje i v našich podmínkách. Relevantnost prrípravy vyšších důstojníků lze zajistit cestou kontinuálních úprav obsahu, forem a metod této prŕípravy, nebo přijetím zcela nové koncepce. Takovou v současnosti předkládá $\mathrm{k}$ diskuzi Univerzita obrany a nejde o změnu dílčí, ale podstatnou, $\mathrm{v}$ jejímž důsledku má dojít ke změnám v celkovém způsobu a pojetí př́ipravy vyšších důstojníků. Již na úvod je asi užitečné poznamenat, že není důvod se takové změny zaleknout, ale naopak, jde o to ji zvládnout, za účelem dosažení požadované úrovně připravenosti sil.

Př́iprava vyšších důstojníků tvoří součást procesu výstavby ozbrojených sil. Diskuze o změně způsobu př́pravy vyšších důstojníků by proto v prvé řadě měla být zahájena posouzením motivů a potřeb, které nás k takovému kroku vedou. Posoudit, zda a do jaké míry je nutné, aby byl systém přípravy vyšších důstojníků změněn. Pokud je dosaženo shody o potřebě změny a víme, co chceme, a proč, lze přistoupit k hledání optimálního 
řešení, které bude splňovat požadavek objektivity, proporcionality a racionality, nikoliv pouhé referenční zakázky. Dosavadní průběh diskuze tuto posloupnost nezachovává. Není dosud prokázána správnost prvotních východisek a nebyla ani naznačena možná variantní řešení. Zato jsou již zpracovány návrhy studijních plánů jednotlivých kurzů. $\mathrm{Na}$ druhou stranu je diskurz nad přípravou vyšších důstojníků veden dlouhodobě a disponujeme $\mathrm{k}$ tomuto tématu řadou podkladů. To je také i důvodem, proč obsah diskuze zatím ničím nepřekvapuje. Většina z dosud předložených doporučení a závěrů s podporou statistických ukazatelů je shodných s těmi, které jsme měli k dispozici již před pěti a více lety. Nebylo by v této souvislosti od věci si vzpomenout, kdo byl jejich autorem, a také co již jednou bylo principiálně rozhodnuto. Minimálně bychom tím dosáhli úspory času.

Tematika přípravy důstojnického sboru se na stránkách Vojenských rozhledů objevuje pravidelně. Ke škodě věci debata přehlíží některá fakta a z pohledu prošlých 20 let některé příspěvky v této debatě nepostrádají také jistou paradoxnost. Sem patří dva př́spěvky Miroslava Krče. V roce 1996 z pozice vedoucího katedry sociálních věd Vojenské akademie v Brně prosazoval v přípravě důstojnického sboru vysokoškolským studiem a dalším vzdělávání rozšíření výuky společenských věd:

„Od vojenského profesionála očekáváme, že bude odborníkem, a zároveň občansky státotvorně angažovanou osobností. V našich podmínkách převládal přistup: vstupposluchač, výstup-inženýr (absolvent), což je př́stup ryze účelový. Chceme-li toto ryze účelové pojetí zmínit, musime usilovat o spoluvytváření poznání a chování tak, aby pedagogická a vědecko-výzkumná činnost sociálně-politických věd si uchovala svi̊j gnozeologický a praxeologický význam v oblasti obecné teorie i v oborech vysoce specializovaných. Jen tak se může realizovat věčná spirála vzájemného vztahu poznání a praxe, celistvost vztahủ a role občana - společenství - státu - vojenství a armády.... Je známo, že současný vývoj spěje ke globalizaci. Vojenští profesionálové tedy nemohou být jen úzcí specialisté a technokrati, ale intelektuálové se značným rozhledem v humanitárních a kulturnich oblastech, lidé se schopnostmi vidèt věci ve svém vývoji. Cílem vzdělávání musí být rozvinutá lidská a občanská bytost, která není pouze naplněna odbornými znalostmi a informacemi, ale rozumi stavu světa na základě studia př́rodních, technických, humanitních, sociálních a ekonomických aj. věd s jejich nejnovějšími poznatky. " [2]

Poté, co je jeho požadavek po dlouhých letech akceptován a schválen usnesením vlády č. 369 ze dne 18. května 2011 v podobě Bílé knihy o obraně (,,...absolventi nastupují do velitelských funkcí a do funkcí specialisti̊, na které musejí být dobře pripraveni. Proto jsou vzděláváni nejen ve vojenské teorii a patřičné vojenské odbornosti, ale $i$ v historii, právu, politologii, etice, sociologii, psychologii a dalšich společenských a humanitně orientovaných vědách “), [3] a stal se tak v duchu § 21 zákona č. 2/1969 Sb. závazným, [4] prosazuje z pozice vedoucího katedry ekonomie na Fakultě ekonomiky a managementu Univerzity obrany naopak zúžení př́ipravy ve prospěch ekonomie a ekonomiky:

„Je nejvyšši čas, aby se ekonomické vzdèlávání vojenských profesionálů přestalo chápat a uskutečňovat jenom jako parciální činnost náležicí do př́pravy odborníkủ s ekonomickou profilací. Teorie i praxe stále výrazněji poukazuje na to, že je nutné uskutečnit komplexní opatření ve výchovně vzdělávacím systému, stanovujicí značné ekonomické znalosti, reflektující na specifické podmínky armády. Takto orientovaná všestranná připrava vojenského profesionála vytváři prostor pro změnu myšlení, ale i př́stupu, 
v rámci kterého ekonomizace vojenských činností se stává a musí stát záležitostí všech zainteresovaných složek armády jak v rovině výkonné, tak i ř́dicí. Ekonomické vzděláváni $v$ různých studijnich programech a formách můžeme minimálně chápat jako investici, která se navrátí v podobě vyšši produktivity a rozvoje celé ekonomiky. " [5]

Velmi sarkasticky viděno, ta dlouhá, dvě dekády trvající debata o obsahu a podobě př́pravy důstojnického sboru je vedena spíše v duchu př́isloví o lišce chválící svůj chvost. Debata by však měla být vedena z pohledu potřeb výstavby ozbrojených sil, finančních možností českého státu a změn prostředí, ke kterému v České republice došlo a které budou pokračovat. Mění se totiž systémové okolí, v němž ozbrojené síly fungují. V tomto bodě je třeba s prof. Krčem souhlasit:

„,V př́pravě vojenských profesionáli̊ je nutné přizpůsobit systém vzdělávání budoucím kvalitativním a kvantitativním požadavkům rezortu obrany při respektování maximální efektivity vynaložených prostředků a respektováním složitosti trhu práce. " [5]

To předjímá i Bílá kniha o obraně: ,, V systému vzděláváni a výcviku je na základě požadavkü Generálního štábu AČR provedena změna v obsahu vzdělávacích a výcvikových programů tak, aby byly naplněny potřeby ozbrojených sil vyplývající z dlouhodobé udržitelnosti schopností. Jsou provedeny též úpravy organizačních struktur, které povedou k uvolnění vybraných objektů a k integraci logistické podpory. “ [3, bod 6.45]

Citlivou otázkou je však mechanismus stanovení kvalitativních a kvantitativních požadavků rezortu obrany. V roce 2009 a 2010 jsme se totiž na stránkách Vojenských rozhledů ve třech bilančních článcích $[6,7,8]$ snažili upozornit, že se za 20 let transformace české armády zásadně změnilo paradigma, ve kterém se vedla diskuze k potřebám zvyšování vojensko-odborné kvalifikace, a že setrvávání na určitých dogmatech se stává dokonce z určitého hlediska groteskní. Zejména dochází-li k historickému srovnávání určitých atributů fungování vojenské personalistiky v kontextu proměny sociálního účelu ozbrojených sil, jejich velikosti, organizačního členění a počtu organizačních stupňů velení a řízení, kvalifikační a hodnostní struktury.

V procesu rozhodování o výstavbě sil je nutné vnímat, že př́íprava personálu není systém statický, ale dynamický. Př́iprava personálu kontinuálně probíhá a každým dnem se proto mění kvalitativní a kvantitativní ukazatele od kterých odvozujeme úroveň připravenosti personálu v ozbrojených silách. Za absolutními čísly, která autoři referenčního článku uvádějí, se skrývá personál s členitou kvalifikační strukturou, která ve svém celku vytváŕí jeden z hlavních předpokladů pro funkčnost ozbrojených sil, a tím i jejich připravenost. Tato kvalifikační struktura se nejenom kontinuálně mění, ale především se trvale zvyšuje. Ukazuje se, že kvalifikační struktura personálu v ozbrojených silách se zjevně neváže pouze na formální organizační nebo hodnostní strukturu armády, ale má svou vlastní dynamiku, za kterou stojí proměna sociálního účelu ozbrojených sil, jiný člověk s jinými ambicemi. Člověk, který svou kariéru zahajuje v civilním sektoru a do armády vstupuje za tím účelem, aby svou kariéru mohl opět v civilním sektoru mnohem úspěšněji završit. Při rozpadu absolutních čísel na vojenské odbornosti, kvalifikační, kariérovou, služební, hodnostní a věkovou strukturu, vyplyne zcela jiný obraz o skutečném stavu a potřebách.

Na mikroúrovni si to lze přiblížit na příkladu struktury personálu u nově vytvořené Agentury logistiky. Kvalifikační požadavky splňuje 93\% vojáků. Všichni důstojníci splňují požadavek vysokoškolského vzdělání, přičemž 5,5\% praporčíků, poddůstojníků a mužstva má rovněž vysokoškolské vzdělání a další vysokou školu studují! 
Poměr absolventů kurzu generálního štábu k počtu systemizovaných míst, kde je tento kvalifikační požadavek předepsán, je $6: 1$. Kurz vyšších důstojníků je předepsán na 112 systemizovaných místech, přitom na části z nich je přiřazen formální metodikou tvorby tabulek, ale funkce jako taková jej nevyžaduje. Počet důstojníků splňujících kvalifikační požadavek je 79. Dalších 9 sice absolvovalo kurz vyšších důstojníků, ale slouží na funkcích, kde není předepsán. Jinými slovy lze také říci, že téměř každý druhý důstojník u Agentury logistiky je absolventem bud’ kurzu generálního štábu, nebo kurzu vyšších důstojníků. Takový údaj sám o sobě navozuje otázku, zda jsou uvedené kvalifikační požadavky správně nastaveny.

Počet důstojníků, kteří na svých pozicích kvalifikační požadavek kurzu vyšších důstojníků nesplňuje, je 26. Dalších 7 systemizovaných míst není dosud obsazeno. Vojáci, kteří nesplňují kvalifikační požadavky, budou vysláni do kurzu vyšších důstojníků v nejbližších termínech, přestože budoucí struktura hodností na jejich funkcích je nejistá. Účelové a specializační formy přípravy absolvované at' již v České republice, nebo v zahraničí, nejsou v této statistice ani zahrnuty, protože je personální systém statisticky nevykazuje. V roce 2013 absolvovala plná 1/4 vojáků z povolání Agentury logistiky některý z typů kurzů. Lze se domnívat, že i tento stručný výčet dokazuje existenci celoživotního učení v české armádě.

Z toho lze odvodit mnohé, ale pro potřeby článku dostačuje zmínit následující závěry. Takto „překvalifikovaná“ struktura personálu umožňuje pružný přesun významného počtu vojáků mezi hodnostními sbory poddůstojníků, praporčíků a nižších důstojníků prakticky bez omezení. Záleží jen na shodě individuálních ambicí vojáků a potřeb armády. Tím se rozmělňuje i kariérní cesta vojáků mezi jednotlivými úrovněmi kariérových kurzů. Za druhé, absence kariérové přípravy jako součásti procesu celoživotního učení je to poslední, čím by současný systém trpěl. Na vrcholu pomyslné pyramidy potřeb nejsou kariérové, ale specializační kurzy, které umožňují specialistům udržet si aktuální úroveň svých odborných znalostí v souladu s inovačním cyklem a novými produkty ve svých oborech. Dále jazykové kurzy, které jsou prvním předpokladem pro interoperabilitu logistické podpory v aliančním prostředí. V neposlední řadě trend indikuje, že se stále více rozevírají nůžky mezi zvyšující se kvalifikací personálu na jedné straně a z důvodu redukce organizačních stupňů velení a řízení klesající úrovní hodností (funkcí) na straně druhé.

Autoři citovaného vědeckého článku [1] v plné míře nevyužili informace uvedené v personálních ročenkách, které obsahují nejenom údaje o tom, kolik vojáků k danému datu bud' splňovalo, nebo nesplňovalo určitý kvalifikační požadavek, ale také údaje o tom, kolik vojáků a v jakých hodnostních sborech a hodnostech tyto požadavky dokonce překračovalo, a to nejen za roky 2010 a 2011, ale za všechny dostupné roky. Údaje pro kurz generálního štábu jsou shrnuty v tab. 1.

Jak si lze z tab. 1 uvědomit, prošel kvalifikační požadavek absolutoria kurzu generálního štábu od roku 2006 paradoxním vývojem. Přestože je počet důstojníků od roku 1990 na sestupné tendenci a tento trend potvrdila v roce 2011 i Bílá kniha o obraně v podobě doporučení redukovat počet vyšších důstojníků, mezi roky 2007 a 2008 se počet míst s plánovaným kvalifikačním požadavkem nejvyššího kurzu skoro ztrojnásobil, aby se později, s platností novely zákona o vojácích z povolání přinášející restrukturalizaci vojenských hodností, vrátil skoro k původním hodnotám. Tady lze spekulovat o vlivu RMO č.19/2008 Zásady výstavby a systemizace organizačních struktur 
Tab. 1: Kvalifikační požadavek kurzu generálního štábu: plánovaná místa, plnění a hodnostní struktura držitelů certifikátů v letech 2006-2012

\begin{tabular}{|c|c|c|c|c|c|c|c|c|c|c|c|c|c|c|c|c|}
\hline \multirow{4}{*}{ rok } & \multicolumn{16}{|c|}{ Požadavek } \\
\hline & \multirow{3}{*}{$\begin{array}{l}\text { 营 } \\
\text { 总 } \\
\text { 竞 }\end{array}$} & \multirow{3}{*}{ 䒿 } & \multirow{3}{*}{$\frac{\stackrel{0}{\Xi}}{\text { 昜 }}$} & \multirow{3}{*}{ 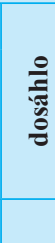 } & \multicolumn{12}{|c|}{ z toho } \\
\hline & & & & & \multicolumn{5}{|c|}{ generálové } & \multicolumn{3}{|c|}{ vyšší důstojníci } & \multicolumn{2}{|c|}{$\begin{array}{c}\text { nižší } \\
\text { důstojníci }\end{array}$} & \multirow{2}{*}{ 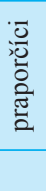 } & \multirow{2}{*}{$\begin{array}{l}\text { D } \\
\text { on } \\
\text { in } \\
\text { ?N } \\
\exists\end{array}$} \\
\hline & & & & & OF & OF & & OF7 & OF6 & OF5 & OF & OF & OF 2 & OF1 & & \\
\hline 2006 & 72 & 56 & 16 & 13 & 1 & 2 & & 14 & 13 & 78 & 26 & 1 & - & - & - & - \\
\hline 2007 & 77 & 59 & 18 & 15 & - & 3 & & 9 & 12 & 101 & 29 & 1 & - & - & - & - \\
\hline 2008 & 207 & 99 & 108 & 15 & - & 3 & & 10 & 11 & 106 & 23 & 1 & - & - & - & - \\
\hline 2009 & 186 & 89 & 97 & 13 & 1 & 3 & & 5 & 11 & 101 & 15 & 1 & - & - & - & - \\
\hline 2010 & 89 & 64 & 25 & 13 & 1 & 2 & & 5 & 12 & 99 & 11 & - & - & - & - & - \\
\hline 2011 & 86 & 60 & 26 & 11 & 1 & 1 & & 7 & 13 & 87 & 9 & - & - & - & - & - \\
\hline 2012 & 83 & 63 & 20 & 12 & - & 1 & & 7 & 10 & 93 & 9 & - & - & - & - & - \\
\hline
\end{tabular}

Poznámky: Od 1. 1. 2011 hodnostní kód NATO OF2 odpovídá hodnosti „kapitán“ a OF1 hodnostem „poručík“ a „nadporučík“.

Do 31. 12. 2010 hodnostní kód NATO OF2 odpovídala hodnostem „kapitán“a a,nadporučík“ a OF1 hodnostem ,pporučík“a ,podporučík“.

Pramen: Statistická ročenka. 2006-2013. [12]

v rezortu MO ČR a změně a doplnění RMO č. 20/2007 Zásady tvorby systemizovaných mist provedenými v roce 2008. Obsah obou vnitřních norem nebyl založen na teorii výstavby sil a vedl k důsledkům, které se zřetelně projevily právě v roce 2013.

V kontextu mikropř́kladu Agentury logistiky je fascinující celková bilance mezi počtem vojákủ, kteří dosáhli daný kvalifikační požadavek, kteří na svých funkcích tento požadavek splňují, a kteří jej naopak nesplňují. Jak vyplývá z tab. 1, kvalifikace poskytnutá vojákům za prostředky daňových poplatníků během jejich důstojnické kariéry je $\mathrm{v}$ mnoha prípadech nevyužita. Personální systém není schopen obsazovat místa s kvalifikačním požadavkem kurzu generálního štábu vojáky, které sám vygeneroval, když vojáky v rámci jejich služebního poměru na taková studia vyslal. Systém př́ípravy personálu tím začíná vykazovat prvotní znaky soběstačnosti a nezávislosti na potřebách systému. Podobná je i situace v případě kurzu vyšších důstojníků, shrnutá v tab. 2.

Ve srovnání s tab. 1 vyplývají z tab. 2 dvě daleko závažnější skutečnosti. První je fakt, že počet osob nesplňujících stanovený kvalifikační požadavek kurzu vyšších důstojníků je víceméně stabilní. To při snižujícím se počtu plánovaných požadavků znamená růst podílu těchto osob. Protože údaje v personalistických ročenkách jsou pořizovány jako stavy v období prvních pěti až osmi dnů roku následujícího po roku, k němuž je ročenka vydávána, je pozoruhodná hlavně skutečnost, že k zásadnímu nárůstu počtu vojáků nesplňující kvalifikační předpoklad kurzu vyšších důstojníků došlo přechodem na novou strukturu hodností k 1. 1. 2011.

Je zvláštní, že byli-li takoví vojáci tzv. povýšeni ze zákona, měl jim být kvalifikační požadavek automaticky prominut. Kvalifikační požadavky se totiž stanovují na základě 
Tab. 2: Kvalifikační požadavek kurzu vyšších důstojníků: plánovaná místa, plnění a hodnostní struktura držitelů certifikátů v letech 2006-2012

\begin{tabular}{|c|c|c|c|c|c|c|c|c|c|c|c|c|c|c|c|}
\hline \multirow{4}{*}{ rok } & \multicolumn{15}{|c|}{ Požadavek } \\
\hline & \multirow{3}{*}{ 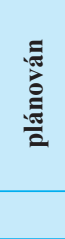 } & \multirow{3}{*}{$\frac{\stackrel{0}{\Xi}}{\text { 方 }}$} & \multirow{3}{*}{ 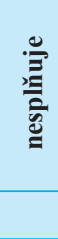 } & \multirow{3}{*}{$\begin{array}{l}\text { 을 } \\
\text { 을 } \\
\text { है }\end{array}$} & \multicolumn{11}{|c|}{$\mathrm{z}$ toho } \\
\hline & & & & & \multicolumn{4}{|c|}{ generálové } & \multicolumn{3}{|c|}{ vyšší důstojníci } & \multicolumn{2}{|c|}{$\begin{array}{c}\text { nižšíi } \\
\text { důstojníci }\end{array}$} & \multirow{2}{*}{ 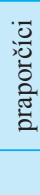 } & \multirow{2}{*}{ 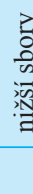 } \\
\hline & & & & & OF9 & OF8 & OF7 & OF6 & OF5 & OF4 & OF3 & OF2 & OF1 & & \\
\hline 2006 & 2554 & 1887 & 667 & 2248 & - & - & - & 2 & 189 & 815 & 881 & 357 & 2 & 1 & 1 \\
\hline 2007 & 2540 & 1960 & 580 & 2316 & - & - & - & 2 & 182 & 845 & 910 & 371 & 2 & 4 & \\
\hline 2008 & 2478 & 1852 & 626 & 2218 & - & - & - & 1 & 171 & 851 & 848 & 335 & 6 & 5 & 1 \\
\hline 2009 & 2312 & 1729 & 583 & 2038 & - & - & - & 3 & 158 & 804 & 786 & 280 & 3 & 2 & 2 \\
\hline 2010 & 2236 & 1603 & 633 & 1850 & - & - & - & 2 & 194 & 770 & 636 & 215 & 28 & 4 & 1 \\
\hline 2011 & 2161 & 1511 & 650 & 1715 & - & - & - & - & 195 & 725 & 573 & 194 & 23 & 3 & 2 \\
\hline 2012 & 2122 & 1539 & 589 & 1730 & - & - & - & 2 & 190 & 707 & 611 & 196 & 18 & 4 & 3 \\
\hline
\end{tabular}

Poznámky: Od 1. 1. 2011 hodnostní kód NATO OF2 odpovídá hodnosti „kapitán“a OF1 hodnostem „poručík“ a „nadporučík“.

Do 31. 12. 2010 hodnostní kód NATO OF2 odpovídala hodnostem „,kapitán“ a „nadporučík“ a OF1 hodnostem ,poručík“ a ,podporučík“.

Pramen: Statistická ročenka. 2006-2013. [12]

vnitřních předpisů, a ty nemohou být v rozporu obecně závaznými právními předpisy. V opačném př́ípadě měly být ze zákona povýšené osoby přednostně vyslány právě na kurz vyšších důstojníků, nebo měly být nahrazeny vojáky, kteří daný požadavek splňovali.

To zejména, platí-li stále ustanovení paragrafu § odst. 3 zákona č. 221/1999 Sb., o vojácích z povolání, ve znění pozdějších předpisů:

„Služební orgány jsou povinny zajištovat rovný přistup a rovné zacházení se všemi uchazeči o povolání do služebního poměru (dále jen ,,uchazeč“) a se všemi vojáky při vytvárení podmínek výkonu služby, zejména pokud jde o odbornou prípravu a dosažení služebního postupu, odměňování, jiná peněžitá plnění a plnění peněžité hodnoty. Je zakázána diskriminace uchazeču a vojáků z důvodu rasy, barvy pleti, pohlaví, sexuální orientace, víry a náboženství, národnosti, etnického nebo sociálního pưvodu, majetku, rodu, manželského a rodinného stavu a povinností k rodině, těhotenství nebo mateřství anebo proto, že vojákyně kojí. Je zakázáno i takové jednáni služebních orgánů, které diskriminuje nikoliv přimo, ale až ve svých di̊sledcích. Za takové jednání se považuje i navádění k diskriminaci. Za diskriminaci se nepovažují př́pady, kdy je pro odlišné zacházení věcný dơvod spočivající v povaze služby, kterou voják vykonává, a který je pro výkon této služby nezbytný. “

Z toho, co se odehrálo v roce 2011 a posléze, to vypadá, že další vzdělávání (celoživotní učení) v dosažení služebního postupu fakticky nehraje očekávanou roli. Minimálně nehraje takovou roli, jakou jí připisují zástupci rezortní akademické obce. Pokud i za této situace, kdy personální systém není schopen v současném období nestability respektovat a využívat dosažené kvalifikace vojáků, existuje tlak na plošné „prohánění“ 
vojáků kariérními kurzy, pak již nejde o kariérní přípravu založenou na výběru do kurzů jakožto předpokladu pro povýšení, ale o všeobecný výcvik.

Druhou skutečností, vyplývají z tab. 2, je fakt, že s kvalifikačním požadavkem vyšších důstojníků se zachází daleko volněji, než tomu bylo v př́ípadě kurzu generálního štábu. Česká republika poskytuje tuto formu vojenské přípravy vojákům, kteří eventuálně skončí vojenskou kariéru v hodnostním sboru praporčíků a dokonce poddůstojníků! V samotné Armádě České republiky se v poslední době stal hnacím motorem zájmu o absolvování kurzu vyšších důstojníků výběr osob na vedoucí funkce. Za absolvování kurzu byly totiž udělovány kandidátům preferenční body. V případě, že by existovalo důsledné řízení kariér, došlo by jistě ke snížení deficitu v kvalifikačním předpokladu kurzu vyšších důstojníků. Spekulativně si lze klást otázku, proč se tak doposud neděje, jestliže již dávno informační systém o službě a personálu dokáže identifikovat vojáky překračující kvalifikační požadavky nebo je naopak nesplňující; to při existenci zmiňovaného státem zaručeného práva na rovný přistup $\mathrm{k}$ odborné př́ípravě a následné dosažení služebního postupu.

\section{Není kurz jako kurz}

Na samotný vývoj systému interní odborné prrípravy důstojníků je vhodné nahlížet především požadavky praxe. Rozsah a obsah přípravy důstojníka se vždy řídil potřebami jeho předurčení, tj. vojskovými požadavky (a právě proto se do Bílé knihy o obraně dostal výše citovaný bod 6.45).

Takové požadavky před rokem 1990 definovaly jak profil absolventa vojenské vysoké školy, tak také potřebu jeho další př́ípravy. V Československé lidové armádě (ČSLA) se proto hovořilo o vojensko-odborném vzdělání, nebo alespoň takto to zmiňuje ročenka 1989. [9]

Vojensko-odborné vzdělání mělo u důstojníků charakter graduální - př́íprava důstojníků byla považována oproti jiným hodnostem za nejvyšší druh vojenské kvalifikace a postgraduální, kde pro specifikované funkce byl požadován vyšší kvalifikační standard vyjádřený skupinou odborností, nebo vojenským kurzem. Zde také nelze zapomínat na to, že tehdejší příprava důstojníků na vojenských vysokých školách probíhala v univerzitní, pětileté formě, a neuniverzitní, čtyřleté, prakticky orientované formě. [10]

Do první kategorie patřila např. Vojenská akademie Antonína Zápotockého v Brně, do druhé pak Vojenská vysoká škola pozemního vojska trojnásobného hrdiny ČSSR a hrdiny SSSR armádního generála Ludvíka Svobody ve Vyškově.

Rozdíl v předurčení i kvalitě obou studií lze mj. dovozovat z citace z jednoho z vojensko-politických zápisníků:

„, Vojenská akademie Antonína Zápotockého v Brně (VAAZ) připravuje vysoce kvalifikované technické kádry pozemního vojska ČSLA ve vybraných studijních oborech... Vojenská vysoké škola pozemního vojska trojnásobného hrdiny ČSSR a hrdiny SSSR armádního generála Ludvika Svobody ve Vyškově na Moravě poskytuje posluchačùm vysokoškolské vojensko-odborné vzdělání a vysokoškolské inženýrské nebo inženýrskoekonomické vzdělání pro výkon základních a středních di̊stojnických funkcí. " [11]

Při přechodu na vyšší důstojnickou funkci bylo zejména u absolventů čtyřleté formy vysokoškolského studia nutno počítat s vojensko-odborným kurzem. 
Absolutorium vysokoškolského vzdělání bylo tehdy stejně jako dnes kvalifikačním předpokladem a absolutorium dalších kurzů v průběhu trvání služebního poměru vyplývalo z kvalifikačních požadavků, tj. specifik daného služebního zařazení.

Takto se sledovala kvalifikace vojáka získaná před vstupem do služebního poměru, během vojenské služby a kvalifikace interní (vojenská) a externí využitelná na trhu práce. Takový model zohledňuje i současné rozlišení kvalifikačních předpokladů (dosažené vzdělání) a kvalifikačních požadavků (kompetence požadované pro výkon služebního zařazení). V př́padě vojenských škol včleněných do národní vzdělávací soustavy mohlo však v některých př́ípadech docházet ke splývání obou kategorií, např. v případě inženýrsko-ekonomického vzdělání.

V rámci původního systému kvalifikací, z něhož se vyvinul i současný systém používaný v Armádě České republiky, existovalo k 1. 1. 1990 v ČSLA 41717 systemizovaných míst pro důstojníky a generály. Z nich bylo vyžadováno základní vojenské vzdělání na 21867 místech; 2087 míst bylo určeno pro absolventy Vojenské politické akademie, 9581 míst pro absolventy Vojenské akademie. U 522 míst byla vyžadována kvalifikace vědeckého pracovníka (CSc., DrSc.), u 1607 míst byla vyžadována vědeckopedagogická kvalifikace a u 189 míst byl plánován vědeckotechnický kvalifikační stupeň. U 2762 míst nebylo plánováno žádné vzdělání. Civilní vysoká škola byla plánována u 1386 míst. V př́ípadě lékařů pak byla plánována civilní vysoká škola a příslušná atestace u 1183 míst. [9]

Za 20 let svého vývoje se však kvalifikační systém pro důstojníky a generály značně zjednodušil, jak lze dovozovat z tab. 3. Dnes jde fakticky jen o tři kvalifikační požadavky: (základní) důstojnický kurz, kurz vyšších důstojníků a kurz generálního štábu. Do konce roku 2005 se v duchu požadavku poskytovat přípravu pro výkon vyšších funkcí, než pro které byli vojáci připravováni ve vojenských školách, dále rozlišovaly: operační velitelský a operačně štábní kurz, brigádní velitelský/štábní kurz a praporní velitelský/štábní kurz. V tab. 3 jsou tyto kurzy ztotožněny s vyššími akademickými kurzy a akademickými kurzy. Nejvyšší vojenskou kvalifikaci v ČSLA představovalo absolvování vojenské akademie GŠ OS v Sovětském svazu, a to ve velitelském (Vorošilova akademie) nebo štábním (Frunzeho akademie) směru.

Při interpretaci vývoje zachyceného v tab. 3 lze postřehnout, že postupně došlo k rozpadu institutu vojensko-odborného vzdělání a že se zvýšil podíl osob s kvalifikací pro službu v hodnostním sboru vyšších důstojníků. $[6,8] \mathrm{K}$ tomu přitom došlo souběžně se saturací důstojnického stavu vysokoškolským vzděláním, a to přesto, že vysokoškolské vzdělávání bylo $\mathrm{v}$ principu unifikováno setřením rozdílů v délce studia mezi vysokoškolskými studijními programy Vojenské akademie v Brně a Vysoké vojenské školy pozemního vojska ve Vyškově a zařazením doktorského studia na školách, které původně nebyly univerzitami. To byl také případ Vysoké vojenské školy pozemního vojska ve Vyškově.

S vysokoškolským zákonem z roku 1990 se všechny vysoké školy automaticky staly univerzitami a začaly poskytovat pětileté magisterské studium souvislé, nebo dělené do tříletého bakalářského studia, po kterém mohlo následovat dvouleté magisterské studium. Při konfrontaci údajů tab. $3 \mathrm{~s}$ předešlými dvěma tabulkami se nabízí otázka, zdali se za těch 20 let stal vojenský svět složitější profesionalizací ozbrojených sil, redukcí jejich počtu, zjednodušením systému velení a řízení cestou snížení počtu řídících stupňủ a odstoupením od požadavku nepřetržité bojové pohotovosti ozbrojených sil, a jejich dislokací do několika posádek a dislokačních míst? 
Tab. 3: Kvalifikační požadavky u českých generálů a důstojníků v letech 1990, 1994 a 2006

\begin{tabular}{|c|c|c|c|}
\hline & $1990^{\text {a) }}$ & $1994^{\text {b) }}$ & $2006^{\mathrm{a})}$ \\
\hline základní vojenské vzdělání & \multirow{2}{*}{21867} & 1651 & \multirow{3}{*}{4339} \\
\hline vojenská vysoká škola & & 11016 & \\
\hline Vojenská akademie & 9581 & 3482 & \\
\hline Vojenská politická akademie & 2087 & - & - \\
\hline vyšší akademické kurzy & 375 & 15 & 496 \\
\hline vojenská akademie GŠ OS & 157 & 99 & 63 \\
\hline akademické kurzy & - & 149 & 1770 \\
\hline vědečtí pracovníci & 522 & \multirow{3}{*}{366} & - \\
\hline vědeckopedagogičtí pracovníci & 1607 & & - \\
\hline vědeckotechnický kvalifikační stupeň & 189 & & - \\
\hline vysoká škola civilní a atestace (základní a nadstavbové) & 1183 & - & 273 \\
\hline vysoká škola civilní & 1386 & - & - \\
\hline Neplánováno & 2762 & - & $174^{c)}$ \\
\hline CELKEM & 41716 & 16778 & 7115 \\
\hline
\end{tabular}

Poznámka: a) plánováno b) skutečnost c) dopočteno

Pramen: Statistické ročenky 1989, 1993, 2005. [9, 13, 14]

Obtížně se diskutuje také s tezí: „Autoři článku měli možnost v posledních letech navštivit a porovnat obsah a úroveň připravy di̊stojnických kurzů v USA, ve Francii, v Rakousku, na Slovensku, v Polsku, i napřiklad v Ázerbajdžánu. Kvalifikovaně lze ř́ci, že co do kvality obsahu i kvality vzdělávání jako takového se nemá za co rezort obrany stydět. Problém ale je v tom, že z pohledu zaměrení kariérových kurzů a výstupní připravenosti absolventů na budoucí zastávané funkce nejsme kompatibilní s našimi aliančními partnery. Hledáme tak velmi obtížně ekvivalenty mezi kurzy doma a v zahraničí. To má za di̊sledek obtižné stanovování návaznosti našich a zahraničnich kurzů. " [1]

Tento odstavec jistě uspěje ve zprávě ze zahraniční služební cesty, ale máme-li: „,...otevřit patřičnou diskuzi a hledat co nejrychleji přijatelné řešení a nalezení nového, funkčniho, perspektivního a kompatibilního modelu. " [1] pro seriózní debatu vedenou na stránkách vědeckého časopisu je neuchopitelný. V části hovořící o kompatibilitě není ani věcně správný. Dostáváme se tím zpět ke kategoriím účel, typ a velikost ozbrojených sil, kde mezi členskými zeměmi NATO existují diametrální odlišnosti. Proto i obsah studia na National Defense University ve Washingtonu bude objektivně vykazovat výraznou odlišnost od př́pravy v kurzu generálního štábu na Univerzitě obrany v Brně. U rozboru situace na Slovensku, v Belgii, v USA a ve Francii se prritom neobjevuje žádný odkaz na veřejně dostupné materiály potvrzující pravdivost uvedených výroků a v seznamu literatury je jen odkaz na kanadský materiál z roku 2011. Skoro to působí dojmem, že se již nehledá řešení, že diskuze sice byla otevřena, ale ve skutečnosti jde o pouhý řečnický obrat. 


\section{Paradox vývoje posledních deseti let}

Že je diskuze o potřebě kurzů generálního štábu a vyšších důstojníků vedena spíše povrchně, doložili oba autoři absencí analýzy dat, které představují jeden z jejich hlavních argumentů. [1] K takovému rozboru mohli použít data z měsíčních výkazů o počtech personálu rezortu Ministerstva obrany. Tab. 4 poskytuje základní deagregaci rezortních dat, s nimiž oba autoři pracovali, když z rezortních dat vyčleňuje Armádu České republiky, jako nejvýznamnějši složku rezortu Ministerstva obrany.

Tab. 4: Vývoj počtu vyšších důstojníků a generálů v rezortu Ministerstva obrany v letech 2004 až 2013

\begin{tabular}{|c|c|c|c|c|c|c|c|c|c|c|c|c|c|c|c|}
\hline & \multicolumn{5}{|c|}{ Rezort Ministerstva obrany } & \multicolumn{5}{|c|}{$\begin{array}{l}\text { z toho Armáda České } \\
\text { republiky }\end{array}$} & \multicolumn{4}{|c|}{$\begin{array}{l}\text { podíl vyšších } \\
\text { důstojníků } \\
\text { Armády ČR } \\
\text { na rezortních } \\
\text { počtech }(\%)\end{array}$} \\
\hline & & G & plk. & pplk. & mjr. & VD & G & plk. & pplk. & mjr. & VD & plk. & pplk. & mjr. & VD \\
\hline & & & OF5 & OF4 & OF3 & & & OF5 & OF4 & OF3 & & OF5 & OF4 & OF3 & \\
\hline \multirow[t]{2}{*}{ 1. 4.2004} & $\mathrm{P}$ & 51 & 382 & 1248 & 1895 & 3525 & 16 & 148 & 519 & 1264 & 1931 & 39 & 42 & 67 & 55 \\
\hline & $\mathrm{S}$ & 24 & 290 & 1157 & 1712 & 3159 & 8 & 126 & 503 & 1190 & 1819 & 43 & 43 & 70 & 58 \\
\hline \multirow[t]{2}{*}{ 1. 1.2007} & $\mathrm{P}$ & 51 & 409 & 1482 & 1649 & 3540 & 16 & 121 & 405 & 985 & 1511 & 30 & 27 & 60 & 43 \\
\hline & $\mathrm{S}$ & 38 & 315 & 1209 & 1525 & 3049 & 12 & 107 & 390 & 926 & 1423 & 34 & 32 & 61 & 47 \\
\hline \multirow[t]{2}{*}{ 1. 1.2013} & $\mathrm{P}$ & 45 & 442 & 1330 & 1369 & 3141 & 9 & 98 & 272 & 687 & 1057 & 22 & 20 & 50 & 34 \\
\hline & $\mathrm{S}$ & 25 & 374 & 1029 & 1109 & 2512 & 3 & 87 & 236 & 576 & 899 & 23 & 23 & 52 & 36 \\
\hline
\end{tabular}

Poznámka: P... plánováno, S...skutečnost

G... generálové, VD... vyšší důstojníci

Pramen: Výkaz personálu rezortu MO k 1. 4. 2004, 1. 1. 2007 a 1. 1. 2013. [12, 14]

Tab. 4 prezentuje vývoj počtu generálů a vy̌šśích důstojníků v rezortu Ministerstva obrany a Armády České republiky ve třech časových řezech: reorganizace Ministerstva obrany k 1. 4. 2004, dosažení počátečních operačních schopností ozbrojených sil ČR k 31. 12. 2006 a počátek roku 2013, ve kterém bylo započato s reorganizací rezortu Ministerstva obrany.

Jednou z jejich motivací bylo snížení počtu vyšších důstojníků, jak se o tom zmiňovala Bílá kniha o obraně v bodě 6.5: „Systém i procesy personálního ř́zení musejí být přizpůsobeny potřebám rozvoje ozbrojených sil ČR. Zejména musí dojít k přizpůsobeni počtu vyššich di̊stojniki a generálů velikosti a úkolüm ozbrojených sil. "

Jak je zřejmé $\mathrm{z}$ tab. 4, ještě v roce 2004 se nejvíce vyšších důstojníků soustřed’ovalo v Armádě České republiky, a to at' už z pohledu plánovaných nebo skutečných počtů. V roce 2013 však počty vyšších důstojníků soustředěných v Armádě České republiky představují jen 1/3 z rezortního počtu! Mezi roky 2004 a 2013 prítom došlo k redukci plánovaných počtů vyšších důstojníků asi o $1 / 7$ a jejich skutečné počty se zmenšily asi o $1 / 6$. Dokonce počet míst plánovaných pro majory v roce 2013 klesl na $1 / 2$ celkových počtu.

Vyšší důstojníci se nejvíce koncentrují u vojenského zpravodajství, Generálním štábu Armády České republiky, na Univerzitě obrany, vojenských nemocnicích. Toto zjištění staví kvantitativní požadavek na kurzy generálního štábu a vyšších důstojníků poněkud 
do jiného světla. Jednak není vůbec jasné, zdali by měl obsah kurzu určovat Generální štáb Armády České republiky. Ten sice reprezentuje Armádu České republiky, ale ta, měřeno podílem vyšších důstojníků ve své struktuře, dnes již nepředstavuje významně dominantní složku.

Budeme-li dále rozklíčovávat potřebu kurzů vyšších důstojníků, je třeba se vypořádat se strukturou odborností. Bílá kniha o obraně v odstavci 6.21 hovoří o tom, že „Základni kariérou je kariéra velitelská. Je charakteristická prolínáním služby na velitelských, štábnich a pedagogických systemizovaných mistech, včetně pưsobeni v zahraničí a nasazeni ve vojenských operacích ".

Při tak malém zastoupení vyšších důstojníků v Armádě České republiky je takřka nemožné zahájit rotaci kádrů $\mathrm{v}$ duchu uvedené teze. Nejdřive by bylo totiž třeba rozpohybovat vojáky v hodnostech plukovníků a podplukovníků. Nastavení hodnostní pyramidy k 1. 1.2011 provedené podle zvolené systemizace fakticky dnes neumožňuje se vracet na funkce v Armádě České republiky, jestliže se voják neocitá v nejvyšších hodnostech v armádě, ale mimo ni, často na místech běžného úředníka.

Opět se ukazuje, že v systému chybí kategorie vojáka - specialisty, jejichž kariéra se řídí specifickými pravidly. Bez zavedení této kategorie zřejmě nebude možné v podmínkách ozbrojených sil o malé velikosti vytvořit stabilní pyramidu hodností, ani kariérní řád. Zde je třeba vidět, že není jednoduché zajistit přechod mezi samostatnými součástmi ozbrojených sil a součástmi rezortu Ministerstva obrany. Také nelze zajistit hodnostní přechod u úzkých specialistů, jako jsou lékařské profese, právníci, př́slušníci duchovní služby, specialisté v technických a ekonomických oborech a další. To byl mj. důvod, proč i v době ČSLA byla jejich kariéra chápána jako systémově autonomní a preferovalo se využívání jejich odbornosti před výstavbou ideální hodnostní pyramidy. I proto byl doposud zachován ekvivalent kurzu vyšších důstojníků u lékařského personálu a právníků.

\section{Závěr}

Vojskové požadavky vždy byly a jsou určující pro kompetence důstojníka v dané odbornosti a hierarchickém postavení. Jestliže ale každý model za posledních 20 let byl doposud nastaven podle budoucích kvantitativních a kvalitativních požadavků rezortu Ministerstva obrany a následně selhal a byl odmítnut, je někde chyba. Její nejpravděpodobnější príícinou je opakované otevírání debaty nikoliv ze strany těch, kdo tyto požadavky určují, ale těch, kdo odpovídající kvalifikaci zajištují. Po 15 letech členství v NATO by se dalo čekat, že již budeme dělat něco víc než stále hledat zahraniční zkušenosti, zvláště v situaci, kdy i zahraniční ozbrojené síly procházejí transformací a hledají také alternativní cesty.

V otevřené diskuzi o problematice př́pravy vyšších důstojníků nikdo nemůže očekávat, že tato se omezí pouze na zpřipomínkování a následné doporučení pouze jedné možné formy této přípravy, bez alternativ, která je do diskuze předkládána. Řešení se mohou nabízet mnohá a je nutné je všechny poctivě posoudit. Obzvláště, pokud chování systému naznačuje, že problém spočívá spíše v personální oblasti, než ve výcviku a vzdělávání. Nelze proto vyloučit, že optimální řešení, které bude nakonec navrženo, může být pravým opakem původních očekávání. Potom se ukáže, zda nám jde o př́ípravu 
takové formy přípravy vyšších důstojníků, která se potká s potřebami ozbrojených sil, bude představovat kvalitativní přínos a bude udržitelná, nebo prostou údržbu a zachování stávajícího uspořádání.

Je potřebné se zamyslet a definovat jaký je vůbec účel a postavení kariérových kurzů ve struktuře vzdělávacích aktivit, kariérových, odborných, specializačních a účelových kurzů. Evidentně se váha jednotlivých typů kurzů liší mezi druhy vojsk a vojenskými odbornostmi. Tím se také liší i důležitost jednotlivých typů kurzů pro zabezpečení funkčnosti ozbrojených sil, tedy jejich připravenosti k použití.

Komplexní pohled na systém přípravy personálu nebyl v posledních letech doceněn. To je i jedním z důvodů vzniku současné situace, která je ještě složitější, než je v tomto článku naznačeno. Musíme se vrátit k jasnému členění forem př́pravy personálu na ty, které slouží k podpoře dosahování vojenských schopností, a na ty, které poskytují všeobecný vzdělanostní základ a zabezpečují kontinuální zvyšování odborné (profesní) kvalifikace. Jinak se nepodaří nastavit v systému př́ípravy personálu priority a splnit vojenské požadavky za podmínek neustále se snižujících výdajů na obranu.

Do jisté míry s překvalifikovanou strukturou personálu souvisí i reálná rizika spočívající v rozporu mezi úrovní individuálních ambicí vojáků a reálnou schopností zaměstnavatele tyto ambice uspokojit. Při jakémkoliv dalším případném snížení úrovně struktury vojenských součástí ozbrojených sil se nemusí podařit personál s vysokou kvalifikací zařadit na funkce, kde by tato kvalifikace našla uplatnění. V takovém prŕípadě výsledkem bude, dříve nebo později, odchod vojáka ze služebního poměru. Statistické údaje z personálního systému ukazují, že jde o vážný problém již nyní. Proč bychom se proto měli domnívat, že v budoucnu bude situace snazší, když vývoj indikuje další prohlubování již dnes existujících anomálií. K tomu by mohlo přispět i plošné spuštění nového modelu kariérových kurzů, pokud by personální systém nedokázal do tohoto systému zapracovat kontrolní mechanismy.

\section{Použitá literatura:}

[1] ZONA, Pavel, ZU゚NA, Pavel. Př́prava velitelského sboru v AČR. Vojenské rozhledy, 2013, roč. 22 (54), č. 3, s. 123-131. ISSN 1210-3292.

[2] Bílá kniha o obraně. 1. vydání, Praha: Ministerstvo obrany ČR - odbor komunikace a propagace (OKP), 168 str. ISBN 978-80-7278-564-3.

[3] Zákon České národní rady o zř́zení ministerstev a jiných ústředních orgánů státní správy České socialistické republiky č. 2/1969 Sb. ze dne 08. 01. 1969, dostupné na http://www.zakonyprolidi.cz/ cs/1969-2.

[4] KRČ, Miroslav. Společenskovědní kultivace vojenských profesionálů. Vojenské rozhledy, 1995, roč. 4 (36), č. 5, s. 31-35. ISSN 1210-3292.

[5] KRČ, Miroslav. Je ekonomické vzdělávání vojenských profesionálů nutné? Vojenské rozhledy, 2012, roč. 21 (53), č. 2, s. 69-76. ISSN 1210-3292.

[6] PERNICA Bohuslav, ZU゚NA Jaromír. Dnes už jiná armáda: změny v systému přípravy nižších důstojníků. Vojenské rozhledy, 2009, roč. 18 (50), č. 3, s. 43-48. ISSN 1210-3292.

[7] PERNICA Bohuslav. Struktura vojenských hodností v letech 1989-2009: Př́liš mnoho důstojníků? (20 let transformace hodnostní struktury). Vojenské rozhledy, 2009, roč. 18 (50), č. 4, s. 114-123. ISSN 1210-3292.

[8] ZŮNA Jaromír, PERNICA Bohuslav. Potřebuje vysokoškolské vzdělání vojenských profesionálů reformu? Vojenské rozhledy, 2010, roč. 19 (51), č. 3, s. 72-83. ISSN 1210-3292.

[9] Statistická ročenka personální správy FMO: rok 1989. Praha: Ministerstvo obrany, 1990.

[10] Vyhláška č. 87/1983 Sb., kterou se vyhlašuje Rozkaz prezidenta Československé socialistické republiky ze dne 15. července 1980 k provedení zákona č. 39/1980 Sb., o vysokých školách, na vojenských vysokých 
školách, ve zněni Rozkazů prezidenta Československé socialistické republiky ze dne 14 . června 1982 a ze dne 12. července 1983.

[11] Vojenskopolitický zápisník 1987. 1. vyd., Praha: Naše vojsko, 1986.

[12] Statistická ročenka. 2006-2013. Praha: Ředitelství personální podpory, 2013.

[13] Statistická ročenka personální správy MO: rok 1993. Praha: Ministerstvo obrany, 1994.

[14] Statistická ročenka 2005. Praha: Ředitelství personální podpory, 2006.

\section{Redakční poznámka}

Práce, kterou autoři předkládají, přináší alarmující informaci nejen o problematickém rozdělení hodností a funkcí s ohledem na kvalifikační stupeň důstojníků, ale upozorňuje svými výsledky na málo srozumitelný stav řízení kariér vojáků z povolání v ozbrojených silách České republiky. Např́klad pouhý údaj o celkovém počtu dejme tomu plukovníků v ozbrojených silách v poměru k jejich počtu v Armádě České republiky nemůže nevyvolat údiv. Podobně jako v hodnostním sboru vyšších důstojníků a generálů, nalézají autoři stejnou neefektivní situaci v ostatních hodnostních sborech. Poměr počtu mužstva a poddůstojníků k počtu rotmistrů a praporčíků, jak ukazují autoři článku, je zcela neefektivní a na první pohled obtížně vysvětlitelný.

Pokus návrhu novely zákona 221/1999 Sb. se pokouší řešit, alespoň částečně, situaci možností jakési „,dobrovolné degradace“. To je zřejmě nepř́liš̌ etické východisko z nouze. Není to konečně poprvé, kdy se vedení rezortu MO k takovému neetickému řešení situace v nepořádném rozmístění a počtu hodností uchyluje. Svědčí to o dlouhodobých rozpacích jak vedení ministerstva, tak Generálního štábu AČR ve věci řízení kariér. Výmluva na dosud neexistující kariérní řád je lichá. Je zřejmé, že jednou z prř́čin toho neuspokojivého stavu jsou chyby spojené s nedostatečnou prŕípravou profesionalizace ozbrojených sil, kdy tvůrci koncepce nevytvořili hodnost vojína.

Další příčinou, trvale zamlčovanou, je zákon o ozbrojených silách, který vytváří z jednotlivých jejich součástí celky do té míry autonomní, že znemožňuje efektivní centrální řízení kariér vojáků z povolání, nemluvě o neúnosné autonomii akviziční. Jsem přesvědčen, že informace v článku obsažené jsou natolik závažné a situace jimi popsaná natolik alarmující, že si žádá co možná rychlé koncepční řešení. Na místě by podle mého názoru byla reakce dejme tomu náčelníka Generálního štábu AČR, ředitele sekce personální MO a ředitele personální agentury při Generálním štábu AČR. Racionální řízení kariér vojáků z povolání, které povede k odstranění disproporcí v článku popsaných, povede i ke snížení hrozivě narůstajícího podílu mandatorních výdajů na rozpočtu rezortu obrany.

Luboš Dobrovský, člen redakční rady Vojenských rozhledů 